\title{
TEACHING RESEARCH METHODOLOGY (TRM) AND SUPERVISING RESEARCH WORK (SRW): CONCEPTIONS, DIFFICULTIES, AND PRACTICES OF LEBANESE UNIVERSITY INSTRUCTORS
}

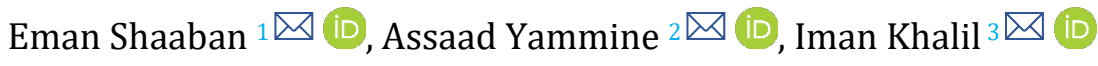 \\ 1, 2, 3 Faculty of Education, Lebanese University, Lebanon.
}

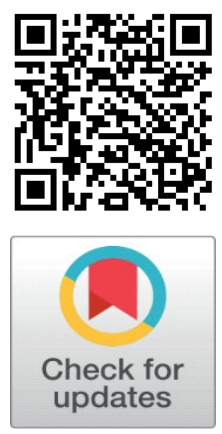

Received 4 September 2021

Accepted 16 September 2021

Published 30 September2021

\section{CorrespondingAuthor}

Eman Shaaban, eman.shaaban@ul.edu.lb

DOI

10.29121/granthaalayah.v9.i9.2021. 4267

Funding: This research received no specific grant from any funding agency in the public, commercial, or not-for-profit sectors.

Copyright: (C) 2021 The Author(s). This is an open access article distributed under the terms of the Creative Commons Attribution License, which permits unrestricted use, distribution, and reproduction in any medium, provided the original author and source are credited.

\section{ABSTRACT}

Research methodology is an essential subject in higher education, however, it is challenging to instructors because of the complexity of the course material. This study aims to highlight the conceptions, difficulties and practices of the Lebanese University research methodology instructors and research work supervisors. For this purpose, research experts constructed and validated a questionnaire. 81 instructors and / or supervisors voluntarily participated. Results showed diversification in conceptions of participants with respect to some common essential concepts within the framework of research methodology, this reflects the complexity of the content and can hinder teaching research methodology (TRM) as well as supervising research work (SRW). Moreover, the participants indicated that they face many difficulties during SRW. The majority of the instructors elaborate their own resources for teaching methodology, they implement student-centered teaching methods and variety of assessment methods allowing students to explore and practice methodology concepts. In addition, they update their knowledge and practices on their own by attending conferences, performing research, discussing with colleagues, and by reflecting on their practices. Thus, our findings imply the need to precise the competencies required for TRM and SRW, and to encourage instructors and supervisors to reflect on their practices and share their experiences.

Keywords: Research Methodology, Research Supervision, Instructors' Conceptions, Difficulties, Practices

\section{INTRODUCTION}

Nowadays, teaching-learning in higher education necessitate the instructors to go beyond what is being practiced to ensure scholarship in teaching and learning, and to engage in professional learning Panda (2017). The five key behaviors for effective teaching in higher education are: lesson clarity, instructional variety, and instructor task orientation, engagement in the learning process and student success rate Alemu (2014). Nunez et al. (2017) discussed the difficulties and problems encountered by instructors, the complexity inherent in their profession, the obstacles they face, and their feeling of unease.

Research methodology is an essential subject in higher education, it is a body of theories, concepts, and tools. According to many studies research methodology courses provide students with the essential skills and knowledge needed to solve various problems in the society and to become successful career researchers Daele (2018), Kilburn et al. (2014),Nayak (2009),Nind et al. (2015). However, research methodology courses are challenging to instructors because of the complexity of the course material and the low interest of students 
Ball and Pelco (2006). Because of this complexity and due to poor performance in methodology course students develop negative attitudes towards the field of methodology Earley (2014), Schober et al. (2006).

On the other hand, research supervision is a complex form of teaching. According to Agricola et al. (2021) it is a teaching process for the supervisor and a learning process for the student. When students are writing their thesis, they need several research skills: e.g., they have to write a research plan; review the literature to develop a conceptual framework; determine the aim and focus of their study; and compose the research questions, and most importantly they should have a skill to develop a proper methodology for data collection and analysis.

There are several practical and pedagogical challenges to teaching research methodology as well as supervision. The well-known and primary challenge is how to make research methods interesting to students. The method employed to meet this challenge is to move away from the direct teacher centered approach of transferring information about research methodology to the creation of an interactive environment where students master technical information through experience, reflection, and critical analysis Braguglia and Jackson (2012),Pfeffer and Rogalin (2012). Thus, in the context of teaching research methods, a combination of student centered and traditional approaches to teaching is a recipe for success Barraket (2005).

This study is part of an Inter-University, Cooperative, Scientific Project (PCSI) supported by the Agence Universitaire de la Francophonie (AUF). The project is entitled: "Pedagogical Innovation in Teaching Methodology and Research Supervision" (Innovation dans les pratiques pédagogiques universitaires de l'enseignement de la méthodologie et l'encadrement des recherches, IPPU).

The project aims to improve the practices of the instructors-researchers at the Lebanese University and enhance their learning in terms of research methodology $(\mathrm{RM})$ and supervision of research work (RW). The theoretical framework of this project is the Scholarship of Teaching and Learning (SoTL) which is generally defined as the " process of developing and valuing the expertise of higher education teachers in teaching subject and about student learning Biémar et al. (2015). SoTL is a model that is used in the higher education (HE) sector (particularly in North America Australasia UK South Africa and some European and south-east Asian countries) to reflect on and transform teaching and learning practices. It invites faculty members to examine their classroom practice, record their successes and failures, and ultimately share their experiences so that others may reflect on their findings and build upon teaching and learning processes Daele (2018),Daele and Sylvestre (2016), Hubball and Clarke (2010). SoTL encourages instructors to reflect on their practices to develop the competencies of the researcher. Thus, it is a methodology for the professional development in the field of higher education teaching, it is a research-led form of professional development Fanghanel (2013).

Moreover, according to Elton (2009) continuous professional development programs for higher education requires: reflection by university management and academics; autonomy to pursue the formulation that 'research into teaching is as important as research in the disciplines'; and shift 'from stressing teaching to stressing learning' (p. 3). Reflective practices require educators to consider their practice and revise as needed to address issues in the classroom or their pedagogy Suter (2012), it can also be a way to achieve professional development Tardif (2012), Thiébaud and Vacher (2020).

The current study is based on the first objective of the IPPU-PCSI project which aims to highlight the practices and difficulties facing research methodology (RM) 
instructors and supervisors of research work (RW) at the Lebanese University in terms of professional development. The Lebanese University is the only institution carrying out the functions of the public higher education in Lebanon where research methodology is taught in all faculties to prepare students for research. To our knowledge no previous studies were implemented in this context.

This study addressed the following research questions:

1) What are the conceptions and difficulties related to teaching of research methodology (TRM) and supervising research work (SRW) at the Lebanese University?

2) What are the teaching practices of Lebanese University research methodology (RM) instructors and supervisors of research work (RW)?

3) What are the practices of Lebanese University research methodology instructors and supervisors reflecting their professional development?

\section{METHODOLOGY}

This study is descriptive analytic implementing the quantitative method. It aims to investigate the conceptions, difficulties, and teaching practices of research methodology (RM) course instructors and supervisors of (RW) at the Lebanese University. Descriptive analysis using SPSS program was implemented to analyze the data collected.

\subsection{PARTICIPANTS}

An invitation to participate in this research project was sent via the Lebanese university e-mail to research work (RW) supervisors and instructors of research methodology (RM) in all faculties and in different fields. Difficulties were encountered to know the precise number of methodology instructors and research supervisors in all faculties. A period of two weeks was given to fill a questionnaire, however few responded, then the period was extended to two months. Finally, 81 participants only voluntarily and anonymously filled the questionnaire. The age of the participants ranges from 35 to 55 years old and they have a teaching experience that ranges from 1 to 10 years. The participants' specialty was classified based on their faculty as either science (pharmacy, medicine, math etc..) or humanity (languages, management, education etc...). Table 1 below presents the profile of the participants.

\begin{tabular}{|ccc|}
\hline Table 1 Profile of Participants & & \\
\hline Profile of participants & & Frequency of Participants \\
\hline Gender & Males & 36 \\
\hline Teaching Language & Females & 45 \\
\hline & English & 30 \\
\hline Specialty & French & 42 \\
\hline & Arabic & 9 \\
\hline Employment status & Science & 45 \\
\hline & Humanity & 36 \\
& Permanent & 47 \\
\hline
\end{tabular}




\subsection{DATA COLLECTION TOOL}

To highlight the conceptions, difficulties, and teaching practices of RM instructors and RW supervisors a questionnaire was constructed and validated.

Six research experts in education from the Lebanese University: four from the faculty of education, one from the faculty of pharmacy, and one from CNAM-Lebanon (conservatoire national des arts et des métiers) collaborated to construct the questionnaire. All experts are participant in the IPPU-PCSI project, and they are instructors of RM and / or supervisors of RW. Based on their practices, teaching and supervising experience, and after reviewing the literature the questionnaire was built along three constructs: Conceptions and difficulties related to TRM and SRW, teaching practices of instructors and supervisors, and professional development practices. Content validity of the first French version of the questionnaire was performed by three research experts in education from the university of Alexandria who are instructors of RM and / or supervisors of RW, and then it was checked by a language expert. Expert peer review using read aloud strategy was performed after building up the items. The experts were asked to read aloud each item in the questionnaire, reflect on it, and give their opinion relative to whether the item fits the construct it implies. Modifications and adjustments were performed accordingly after agreement between all the experts. Then the French version was translated to English by one researcher who is fluent in both languages. In order to validate the translation "back- translation" to French was done by another researcher and questions in both versions were adjusted accordingly, the Standardized forwardbackward translation procedure was applied Koller et al. (2012). The English version was again validated by three research experts from the Lebanese university who are not part of the project and was checked by an English language specialist.

Then the final versions of the questionnaire were piloted on five RM instructors who are also RW supervisors, three English and two French. The aim of the pilot study was to examine the items' comprehensibility and simplicity of language as well as the time needed to answer all items. The notes concerning the language and length of the questionnaire were taken into consideration and modifications were subsequently made on the French and English versions of the questionnaire. For reliability purpose, Cronbach alpha was calculated for all the 76 items of the questionnaire, excluding the personal information. The value of Cronbach $\alpha$ is 0.882 which is greater than 0.8 , so there is a high internal constancy between the questionnaire items.

The final version of the questionnaire is composed of the following parts:

1) Course preparation composed of two parts: first one composed of seven items about the elements of the course to be conveyed to students; second one composed of four items related to resources utilized in course preparation.

2) Teaching practices: 17 items related to different aspects of teaching practices and 6 items related to the types of assessment implemented.

3) Content of the methodology course: 18 items

4) Professional development: 9 items

5) Difficulties faced during research supervision: 15 items

6) Personal information: 11 items 
7) Final part: Email, phone number for those willing to reflect on their practices.

Four-point Likert scale was used in this research mainly because offering neutral options allows participants to move on without giving careful thought to the question Dolnicar et al. (2011). Moreover, this type is preferred since answers can be evenly split into simple dichotomies: Agree and Disagree. The questionnaire was administered online as Google Form in December 2019.

\section{RESULTS AND DISCUSSIONS \\ 3.1. CONCEPTION AND DIFFICULTIES RELATED TO TRM AND SRW}

To highlight the conceptions of the RM instructors and RW supervisors the participants were asked if they agree or disagree on specific definitions about essential concepts related to TRM. The responses of participants are presented in Figure 1.

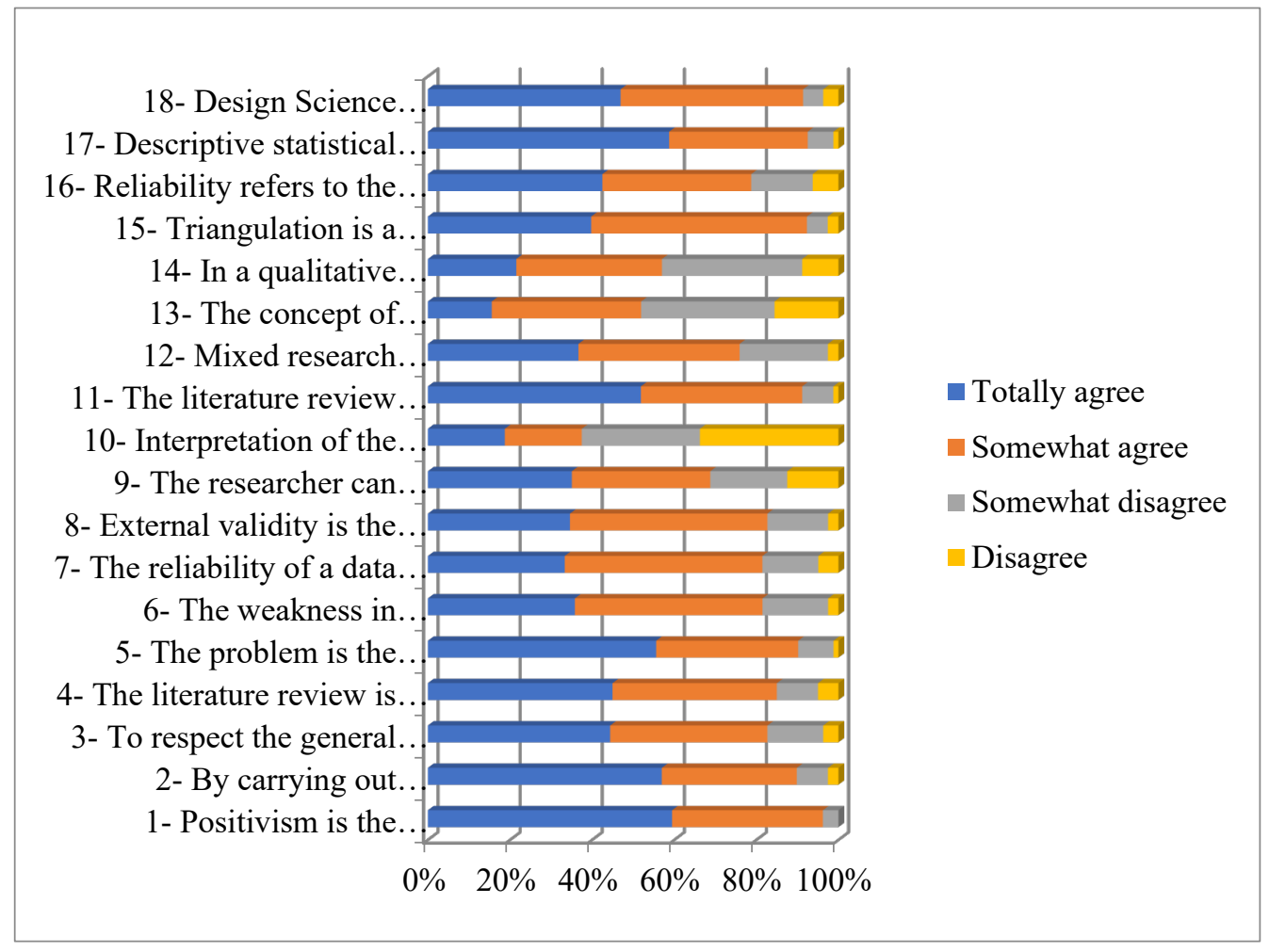

Figure 1 Conceptions of Instructors and Supervisors Concerning Essential Concepts for TRM

A large majority of participants (96.2\%) agree with the commonly used definition of positivism as the philosophical approach according to which the constituted objects of the scientific study must be verified, explained and quantified. However, it is notable that a minority of participants do not agree with this definition. The majority $(89.9 \%)$ consider that by carrying out quantitative research, the researcher has the advantage of enriching the interpretation of the results obtained by qualitative aspects. Remains a notable minority that do not find the benefit of the qualitative aspects in the interpretation of results in quantitative research. However, the majority $(82,7 \%)$ consider that the researcher must be convinced that the theoretical and practical advantages of his research outweigh the 
inconveniences it may have caused to the participants. This goes against the ethical rules of research.

Moreover, (85\%) consider that the literature review is the progressive narrowing of the field of research made possible by the logical and rigorous work of the researcher. This definition does not correspond to that commonly adopted within the Framework of research methodology.

Similarly, a large majority (90.2\%) of the participants reduce the problem of research, which corresponds according to resources within the framework of research methodology to the theoretical and empirical framework within which the object of study is to the question that the researcher asks himself and which reflects his specific problem. Again, the majority (81.5\%) confuse the definition of the specific problem of research, as a weakness in previous work to which we want to shed additional light and this justifies the pursuit of research, with that of the general problem of research which corresponds to one aspect of the research theme.

On the other hand, the majority of participants (81.5\%) do not seem to distinguish between reliability of a data collection tool, which corresponds to always measuring the same phenomenon regardless of the circumstances / identical data for the same participants at different times, and its validity which implies a comparison between the data obtained and an external criterion.

A large majority $(82.7 \%)$ agree with the commonly used definition of who consider that external validity as the possibility of generalizing the results of a research to a situation (and people) other than that those prevailed during the data collection. However, remains a notable minority of methodology instructors and supervisors who do not agree with this definition. Related to hypothesis $31.2 \%$ of respondents consider that the researcher cannot reject the null hypothesis when the probability of obtaining the results of a research is greater than the significance level of 0.05 , which is generally acceptable. $37.5 \%$ of participants find that interpretation of results is essential only when the results do not support predictions.

In addition, $91.1 \%$ of participants consider that the literature review represents specialized critical reading in order to define a specific research problem. $24.1 \%$ of participants disagreed that mixed research methods are often seen as intermediate solutions between two classic epistemological positions in research: the search for an explanation or a universal truth and the search for multiple truths. Opinions in relation to the concept of generalization of results which is used in qualitative research instead of the concept of transferability of results are divided (51.9\% for and $48.1 \%$ against). $57 \%$ of the participants consider that in qualitative research the number of participants is determined from the beginning of the research, which does not correspond to what is commonly known in the context of this type of research.

$92.3 \%$ of respondents consider that triangulation is a strategy for comparing several methods of collecting and interpreting data in order to draw out valid conclusions.

$78.8 \%$ of respondents find that reliability refers to the stability of the data over time.

92.5\% of participants believe that descriptive statistical analysis of data allows the researcher to describe and summarize a set of raw data using statistical tests. $94.9 \%$ of participants agree that science research design allows the development of models and solutions.

Thus, the analysis of the results concerning the conceptions of the research methodology instructors and supervisors showed the systematic absence of consensus among participants about definitions of essential concepts dealt with in 
this research. These common definitions are adapted from well-known resources in the framework of research methodology such as: Cohen et al. (2007), Creswell (2007),Creswell (2005),Creswell (2009),Gaston (2004), Gay et al. (2009), Karsenti(2018). The majority of participants agree with the definitions of certain essential concepts such as triangulation, the advantage of enriching the interpretation of the results obtained by qualitative aspects, the external validity of research, research design, etc.). However, the opinion of participants was divided related to some definitions as they are commonly used in research (generalization, rejection of $\mathrm{H0}$, reliability, number of participants in qualitative research, etc...). In addition, this study showed that the majority of participants agree on definitions that differ from those commonly used in the context of research (the problem of research, research ethics, the reliability of the data collection tool, the literature review, etc...).

All in all, there is a very large diversification of responses: a consensus on concepts' definitions as they are commonly used in research; a consensus on definitions that are not compatible with the commonly used definitions; and a divergence of opinions on certain definitions. In our case, we consider that this diversification can hamper the TRM as well as the SRW.

The current study about the definitions of concepts taught within the framework of research methodology appears to be unique. To our knowledge no previous studies were conducted about instructors' conceptions related to research methodology concepts. Studies were mainly performed on instructors' practices Barraket (2005), Braguglia and Jackson (2012), Earley (2014), Pfeffer and Rogalin (2012), Wilson et al. (2013).

On the other hand, Figure 2 highlights the difficulties faced by the participants during supervision.

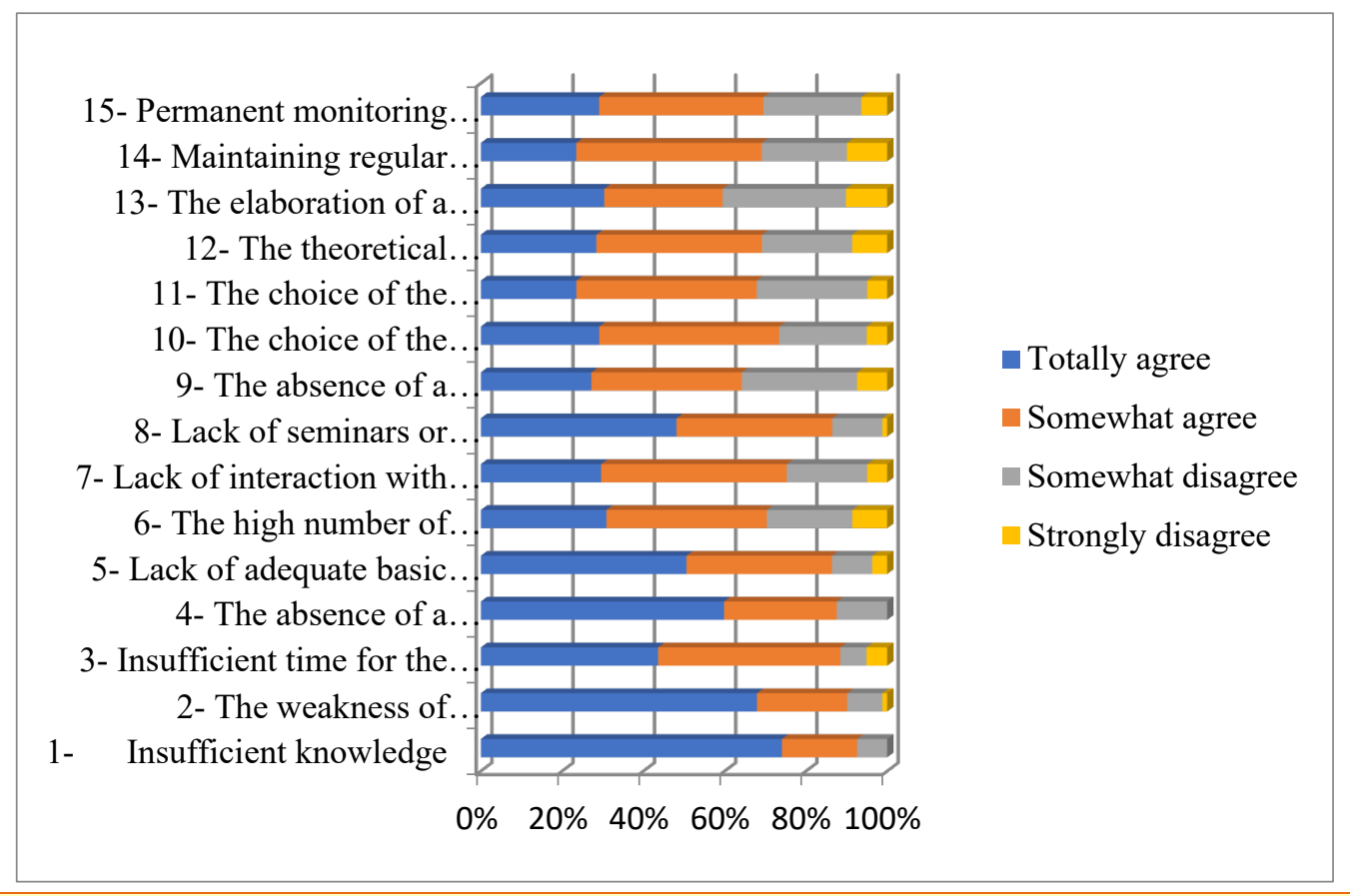

Figure 2 Difficulties Faced during Supervision of Research Work

The majority of participants ( $>85 \%$ ) focused on the difficulties related to students themselves: their insufficient knowledge, weak language, scarcity of seminars that might guide them about new trends in research, not well activated 
research laboratory to support students, and the absence of basic resources for them. In addition to insufficient time for the implementation of all the stages of research. The majority also agreed on difficulties related to the steps of writing research: The choice of the research topic and the construction of the problem, the theoretical framework and the literature review, and the choice of the research method. This is in agreement with the study of Saman et al. (2019) who reported that the main common challenge for both the students and supervisors was the students' lack of research knowledge including, lack of research design knowledge such as analyzing data by SPSS software and choosing a researchable topic.

On the other hand, $58 \%$ to $75.3 \%$, of the participants agreed on difficulties related to: communication with their students and other supervisors; permanent monitoring of the thesis writing; maintaining regular contact with students; elaboration of a work calendar; the high number of students to be supervised; and lack of interaction with other supervisors to discuss the problems faced. This is in agreement with the results of the study of Zaheer and Munir (2020) which revealed that the time constraints, official restrictions, irregular contacts and technology are the main issues faced by supervisors.

\subsection{TEACHING PRACTICES OF INSTRUCTORS AND SUPERVISORS}

To highlight the teaching practices of instructors and supervisors, the participants were asked to classify the elements related to course preparation, classify the resources utilized, rate their practices during teaching research methodology, and identify the types of assessment implemented. Figure 3 shows the participants' classification of the elements related to the preparation of research methodology course.

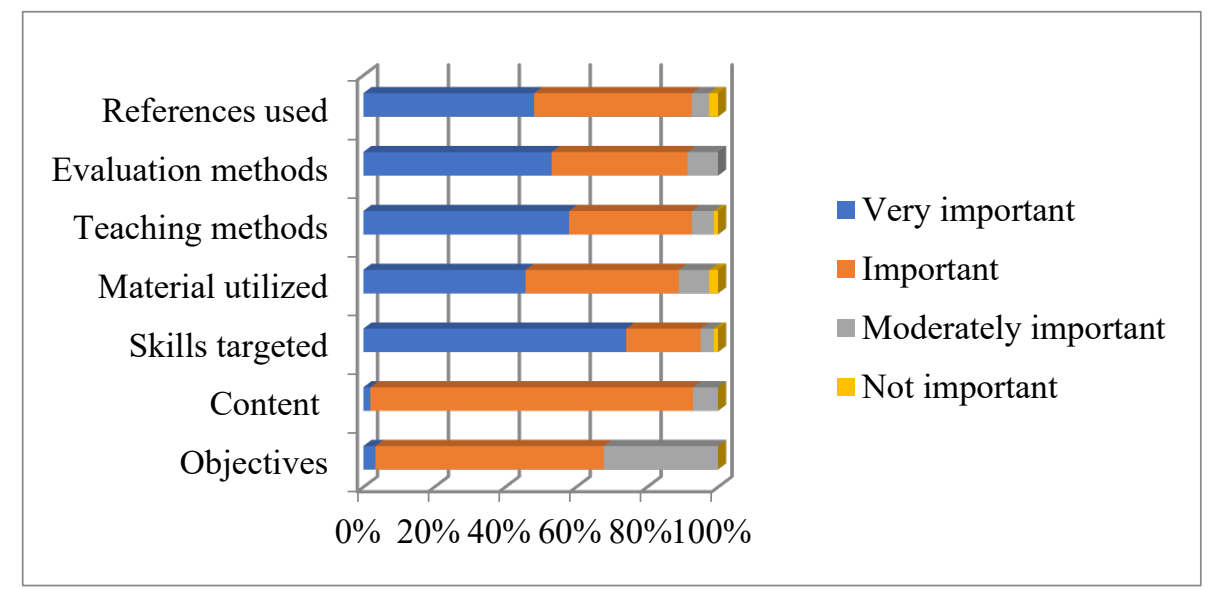

Figure 3 Elements Related to Preparation of Research Methodology Course

The results showed that $77.8 \%$ of the participants consider conveying the objectives of the course very important, $14.8 \%$ consider it important and $7.4 \%$ moderately important. The percentages showed that the sample consider conveying the course objectives, skills targeted and the content of the course to be very important compared to conveying materials, teaching methods, evaluation methods and references used which were considered important. This might indicate that the participants of this research emphasize on the objectives, the content of the course and students' skills during their preparations. This is in congruence with Wilson et 
al. (2013) which highlighted the existence of a possible relationship between prior expectations and the benefits of research methodology course.

Moreover, Figure 4 shows the classification of the resources utilized in course preparation according to their degree of importance for lesson preparation ( 1 being the least important and 4 the most important).

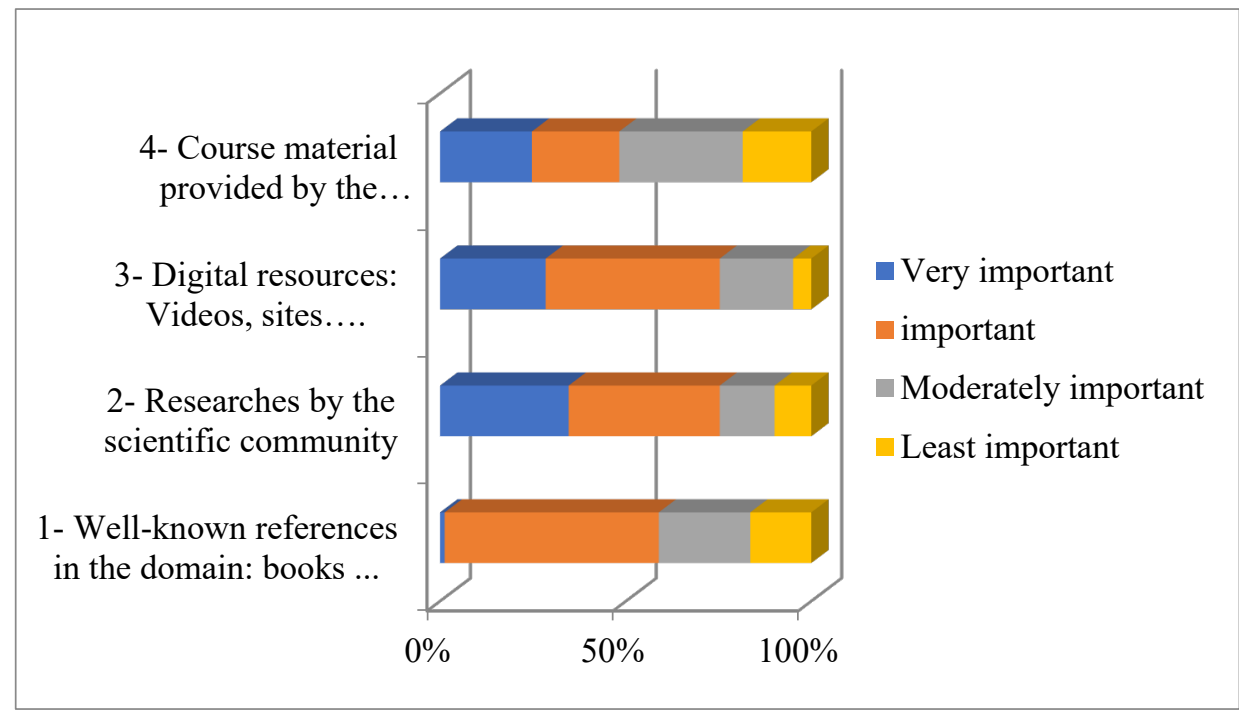

Figure 4 Resources Important for Lesson Preparation

The results showed that the more than $75 \%$ of the participants consider well known references, researches done by the community, and digital resources as important resources for TRM. The least important resource according to participants' responses was the course material provided by university or colleague. This might indicate that instructors build their own resources for teaching methodology based on variety of references.

In addition, Figure 5 shows the percentages of the responses of the participants related to their practices while teaching methodology course. 


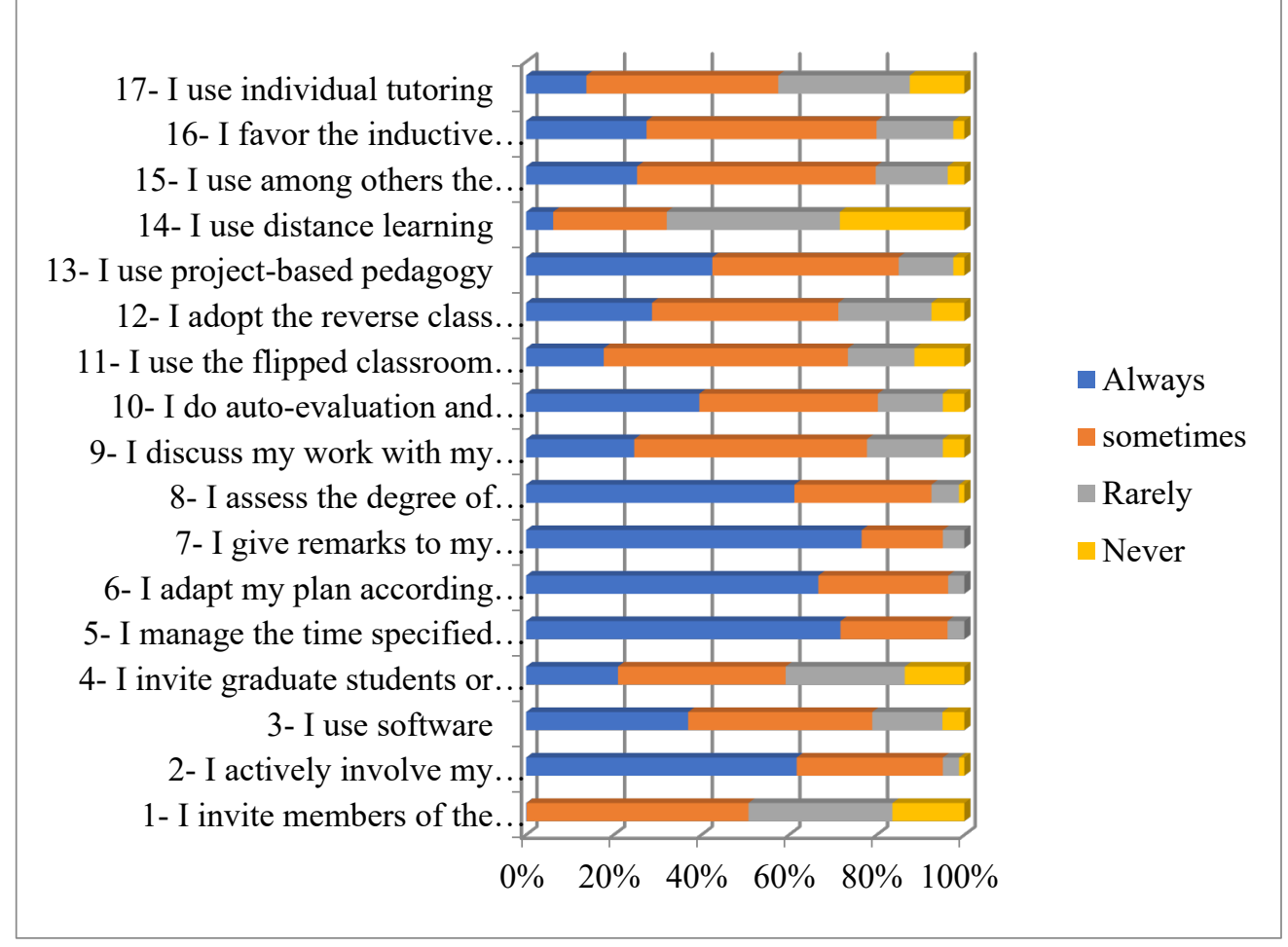

Figure 5 Teaching Practices Related to Research Methodology Course

The results showed that the participants involve students in the learning activities with $79 \%$ favoring inductive approach using project-based pedagogy adopting their plan according to the students' needs and giving them remarks related to their academic progress. However, $77 \%$ are still using lecturing method always or sometimes. It is noticed that around $68 \%$ rarely or never use distance learning and around $72 \%$ use frequently flipped classroom. The majority practice auto evaluation and reflection and discuss their work with colleagues. On the other hand, only $50 \%$ invite experts to their classes and 59\% invite graduate students or students in the process of preparing their research to share their experience. This might indicate that the participants implement active learning giving the opportunity for learners to construct their learning while performing projects. They implement teaching methods that are student centered like flipped classroom and reverse class method (DIY: Do It Yourself). This is in agreement with study of Braguglia and Jackson (2012) that focused on the importance of creating an interactive environment for students to master technical information.

Figure 6 shows the percentages of responses related to the assessment used by instructors of research methodology course. 


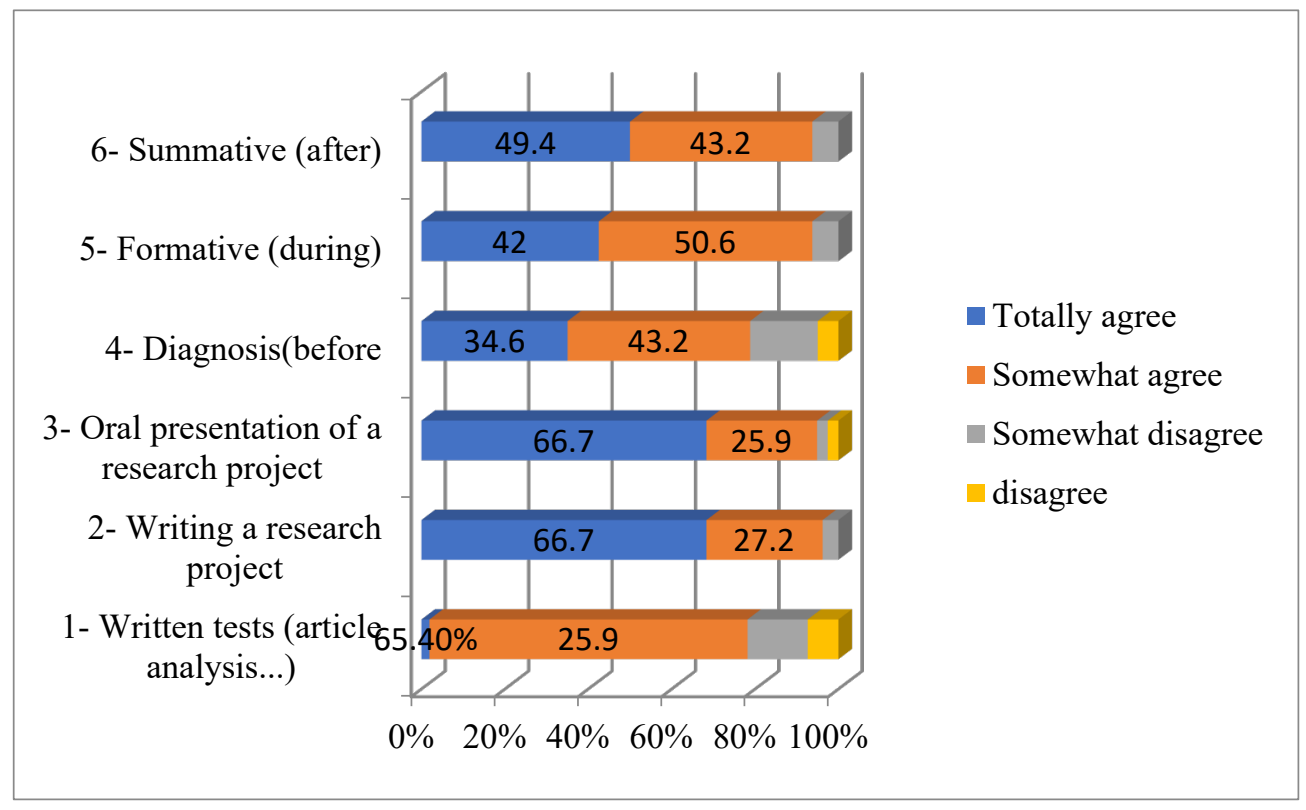

Figure 6 Assessment Methods used by Instructors of Research Methodology Course

Related to assessment the majority of the participants (> $85 \%$ ) are implementing various methods: tests, article analysis, projects and oral presentations. In addition, the majority $>75 \%$ are implementing the three types of assessment: diagnostic, formative, and summative.

\subsection{PROFESSIONAL DEVELOPMENT PRACTICES}

The practices of instructors and supervisors that reflects their professional development are presented in Figure 7.

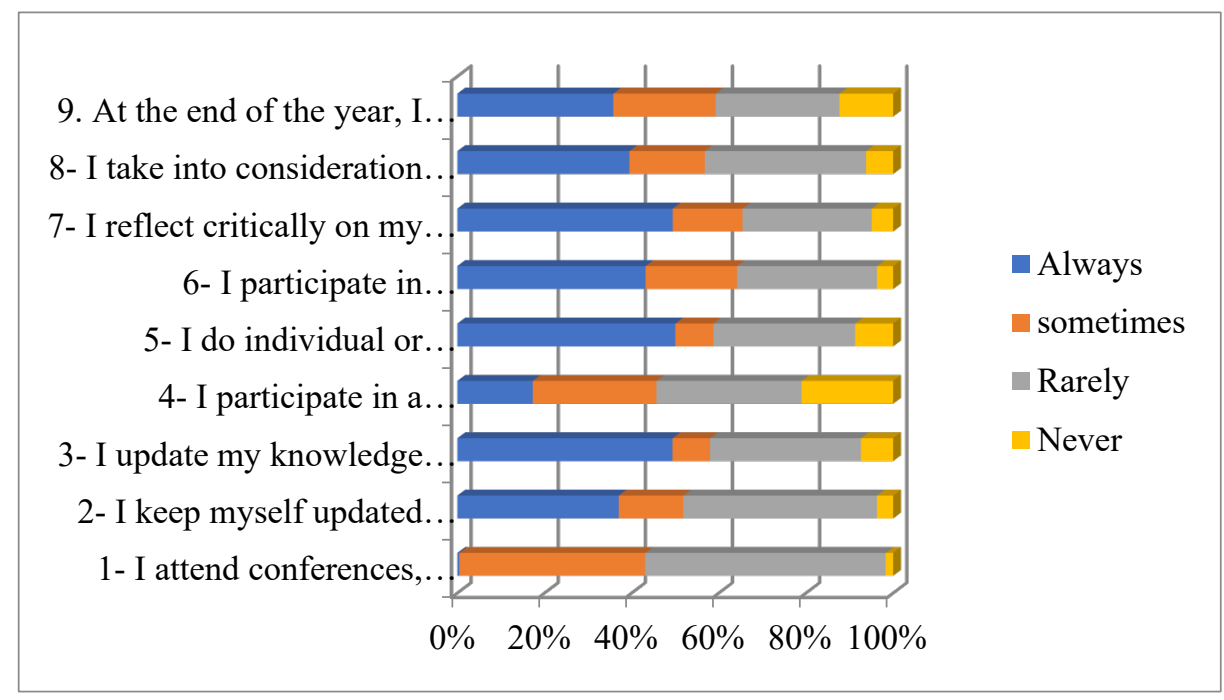

Figure 7 Practices of Participants Reflecting their Professional Development

The results showed that for their professional development $65 \%$ of the participants use reflection on their practices; $64 \%$ rely on discussions with colleagues; $60 \%$ attend conferences. Moreover, $58 \%$ perform research either individually and in collaboration with their colleagues or relay on readings and 
training to update their knowledge and only $52 \%$ updated themselves about the different educational innovations in their field. On the other hand, $59 \%$ relay on their students' evaluation and $57 \%$ take into consideration the performance of their students. However, only $45 \%$ participate in network of teachers formed especially for professional development This might indicate that there is no specific or regular mandatory training or workshops for continuous professional development organized by the faculties of the Lebanese university. This is in congruence with the study of Clegg (2003) which considered that conferences, collaborative projects, faculty exchange, peer review, scholarly publications, online discussions and communications are needed for continuous professional development.

\section{CONCLUSIONS AND RECOMMENDATIONS}

This study aims to highlight the conceptions, difficulties, and practices of RM instructors and RW supervisors at the Lebanese University. For this purpose, a questionnaire was constructed and validated by researchers and experts in the field of education.

Related to the first question of research: What are the conceptions and difficulties related to TRM and SRW at the Lebanese University?

The results showed diversification of participants' conceptions with respect to some commonly used definitions for essential concepts as presented in many wellknown references within the framework of research methodology. The participants consent on certain definitions which are not compatible with those commonly used and their opinions vary with respect to other definitions. This diversification can make it possible to understand the difficulties encountered during TRM and SRW. Despite the fact that the number of returned questionnaires is not excessively high, we can consider that this diversification reflects the complexity of the content of the methodology course Ball and Pelco (2006), and can hinder or impede TRM as well as SRW. In this context, we as instructors and supervisors noticed absence of consensus about certain essential concepts (problem of research, generalization, transferability, reliability etc...) related to TRM during formal discussions (thesis defenses, seminars, workshops...) and informal discussions among the researchers and instructors from different faculties (humanities and sciences) of the Lebanese University and from different universities.

On the other hand, according to the opinion of the participants the difficulties faced during SRW are due to: insufficient knowledge of students about research methodology; not very well activated research laboratory; irregular contact with students; high number of students supervised by one supervisor; and scarcity of seminars. This is in agreement with the results of the study of Zaheer and Munir (2020) which revealed that the time constraints, official restrictions, and irregular contacts are the main issues faced by supervisors. However, based on the researchers' knowledge as instructors at the faculty of education of the Lebanese University, seminars are organized by the Educational Studies \& Research Centre to support both instructors and students. In addition, there are many reseach teams working in collaboration with masters' and doctoral students.

Moreover, the results showed difficulties related to the steps of writing research: The choice of the research topic; the construction of the problem; and the choice of the research method. This is in agreement with the study of Saman et al. (2019) who reported that the main common challenge for both the students and supervisors was the students' lack of research knowledge. All these findings imply the need to identify students' skills and knowledge about research and adapt the 
level and amount of supervision support according to the students' needs. This is aligned with the study of Agricola et al. (2021).

Related to the second question of research: What are the teaching practices of Lebanese University research methodology (RM) instructors and supervisors of $(\mathrm{RW})$ ?

The results of this study showed that the majority of the instructors of research methodology elaborate their own resources for teaching methodology based on specific objectives emphasizing on students' skills. They implement student centered teaching methods giving the opportunity for learners to construct their learning while performing projects. In addition, they utilize variety of assessment methods allowing students to explore methodology concepts and practice them. This kind of pedagogical approaches is recommended in every teaching in general and in teaching methodology in particular Barraket (2005), Kilburn et al. (2014).

Related to the third question of research: What are the practices of Lebanese University research methodology instructors and supervisors reflecting their professional development?

The findings showed that instructors and supervisors update their knowledge and practices in the field of research methodology on their own by attending conferences, performing research and discussions with colleagues, or by reflecting on their practices using students' evaluation and performance. This is in alignment with other studies related to professional development in Lebanon, such as: AlJammal and Ghamrawi (2013) who reported that self-reflection, action research, examining students' work, and informal discussion with peers are important approaches of Lebanese teacher professional development in order to enhance the professional knowledge, skills, and attitudes of educators leaving an impact on students' learning; Jarjoura and Khalil (2016) that showed that faculty members of the Lebanese University use online resources to update their knowledge, prepare students' activities and for research purposes.

Thus, our findings related to conceptions, difficulties, and practices implies the need to precise the competencies required to TRM and SRW; to encourage instructors and supervisors to reflect on their practices, share their experiences, and to practice SoTL as research-led form of professional development. This is in agreement with the study of Nabhani and Bahous (2010) which showed that continuous professional development in Lebanon focuses on workshops with no follow-up of what is learned and emphasized on the need for more structured and systematic programs which focuses on action research and mentoring. It is also aligned with: the study of Panda (2017) which emphasized that professional development necessitates reflective practices on innovative processes and outcomes; and the study of Fowler (2019) which emphasized that reflective practices is the cornerstone for professional development. Moreover, stakeholders at the Lebanese University can consider the results of this study to update the syllabus of research methodology course. In addition, it is recommended to organize more seminars/ webinars for instructors to share their experience and reflect on their practices, and for students to support and guide them during their research work.

In the framework of IPPU-PCSI project a competencey framework for research methodology instructors was developed and validated Khalil et al. (2021) unpublished). In addition, an observation grid for auto-reflection on teaching practices and research supervision was developed.

Future studies will implement analysis of video capsules for research methodology instructors based on the elaborated observation grid. This kind of 
analysis can be used for auto-reflection in order to enhance reflexive practices to achieve professional development Tardif (2012), Thiébaud and Vacher (2020). In addition, further studies will be performed to determine any significant association between certain variables (gender, specialty, language, teaching experience etc...) and RM instructors' and RW supervisors' conceptions and practices. Moreover, future studies should targert students' conceptions and difficulties in the framework of research methodology.

\section{ACKNOWLEDGEMENTS}

This study is supported by the Agence Universitaire de la Francophonie (AUF). It is an Inter-University, Cooperative, Scientific Project (PCSI) between the Faculty of Education of the Lebanese university (Lebanon), Alexandria University (Egypt), and Lausanne University (Switzerland). The three researchers of this study are part of the Lebanese team. We would like to thank all the researchers and experts who participated in this project and especially those who helped in the construction and validation of the questionnaire implemented in this study. We would also like to express our gratitude for Mrs. Nisrine Tannir (CNAM-Lebanon) and Dr. Mohamad Sultan (Alexandria University) for their technical support in SPSS analysis.

\section{REFERENCES}

Agricola, B. T., Prins, F. J., van der Schaaf, Marieke F, \& Van Tartwijk, J. (2021). Supervisor and student perspectives on undergraduate thesis supervision in higher education. Scandinavian Journal of Educational Research, 65(5), 877-897. Retrieved from https://doi.org/10.1080/00313831.2020.1775115

Al- Jammal, K. \& Ghamrawi, N. (2013). Teacher professional development in Lebanese schools. Basic Research Journal of Education Research and Review, 2(7), 104-128. Retrieved from

Alemu, B. M. (2014). Enhancing the quality and relevance of higher education through effective teaching practices and instructors' characteristics. Universal Journal of Educational Research, 2(9), 632-647. Retrieved from https://doi.org/10.13189/ujer.2014.020906

Ball, C.T., \& Pelco, L.E. (2006). Teaching research methods to undergraduate psychology students using an active cooperative learning approach. International Journal of Teaching and Learning in Higher Education, 17 (2), 147-154. Retrieved from https://citeseerx.ist.psu.edu/viewdoc/download?doi=10.1.1.561.2241\&re $\mathrm{p}=\mathrm{rep} 1 \&$ type $=$ pdf

Barraket, J. (2005). Teaching research method using a student-centered approach? Critical Reflections on Practice. Journal of University Teaching and Learning Practice, 12(2), 64-74. Retrieved from https://doi.org/10.53761/1.2.2.3

Biémar, S., Daele, A., Malengrez, D., \& Oger, L. (2015). Le "Scholarship of Teaching and Learning" (SoTL). Proposition d'un cadre pour l'accompagnement des enseignants par les conseillers pédagogiques. Revue Internationale de Pédagogie de l'Enseignement Supérieur, 31(2). Retrieved from https://doi.org/10.4000/ripes.966

Braguglia, K.H. \& Jackson, K.A. (2012). Teaching research methodology using a project-based three course sequence critical reflections on practice. American Journal of Business Education, 5(3), 347- 352. Retrieved from https://doi.org/10.19030/ajbe.v5i3.7007 
Clegg, S. (2003). Problematising ourselves: continuing professional development in higher education. International Journal for Academic Development, 8(1\&2), 37-50. Retrieved from https://doi.org/10.1080/1360144042000277928

Creswell, J.W. (2005). Educational research: Planning, conducting, and evaluating quantitative and qualitative research. Pearson International Edition.

Creswell, J.W. (2007). Qualitative inquiry and research design. Choosing among five approaches. Thousand Oaks: CA, Sage.

Creswell, J.W. (2009). Research design. Qualitative, quantitative and mixed methods approaches. Los Angeles, Sage.

Cohen, L., Manion, L., \& Morrison, K. (2007). Research methods in education. London : Routledge. Retrieved from https://doi.org/10.4324/9780203029053

Daele, A. (2018). Faire de son enseignement un objet de recherche : se défier par l'écriture. Communication présentée à 30ème colloque de l'Association Internationale de Pédagogie Universitaire, Cotonou, Bénin. Retrieved from http://hdl.handle.net/20.500.12162/2638

Daele, A., \& Sylvestre, E. (2016). Comment développer le conseil pédagogique dans l'enseignement supérieur? De Boeck supérieur.

Daniel, B. K. (2018). Reimaging research methodology as data science. Big Data Cognitive Computing, 2 (1), 4-17. Retrieved from https://doi.org/10.3390/bdcc2010004

Dolnicar, S., Grun, B., Leisch, F., \& Rossiter, J. (2011). Three good reasons NOT to use five and seven point Likert items. Retrieved from https://ro.uow.edu.au/commpapers/775

Earley, M. (2014). A synthesis of the literature on research methods education. Teaching in Higher Education, 19(3), 242-253. Retrieved from https://doi.org/10.1080/13562517.2013.860105

Elton, L. (2009). Continuing professional development in higher education: The role of the scholarship of teaching and learning. Arts and Humanities in Higher Education, 8(3), 247-258. Retrieved from https://doi.org/10.1177/1474022209339955

Fanghanel, J. (2013). Going public with pedagogical inquiries: SoTL as a methodology for Faculty professional development. The ISSOTL Journal, 1(1), 29-70. Retrieved from https://doi.org/10.20343/teachlearninqu.1.1.59

Fowler, T. A. (2019). A \#selfie meritocracy in educator professional development: Generating complacency through self-reflection. Canadian Journal for New Scholars in Education, 10(2), 93-101. Retrieved from https://dev.journalhosting.ucalgary.ca/index.php/cjnse/article/view/530 57

Gaston, M. (2004). Méthodes de recherche en sciences de l'éducation, Paris, Presses Universitaires de France, «Que sais-je ?».

Gay, L.R., Mills, G.E. \& Airasian, P. (2009). Educational research. Competencies for analysis and applications. Uppersaddle River, NJ : Pearson international Edition.

Hubball, H., \& Clarke, A. (2010). Diverse methodological approaches and considerations for SoTL in higher education. The Canadian Journal for the Scholarship of Teaching and Learning,1(1). Retrieved from https://doi.org/10.5206/cjsotl-rcacea.2010.1.2 
Jarjoura, C., \& Khalil, I. (2016). Resources, working environment and style of collaboration among science education teaching faculty at Lebanese Universities. International Journal of Science and Research (IJSR), 5(12), 365-371. Retrieved from https://www.ijsr.net/archive/v5i12/ART20163440.pdf

Karsenti, T. (2018). La recherche en éducation : étapes et approches (4e éd.). Montréal : Presses de l'Université de Montréal. Retrieved from https://doi.org/10.2307/j.ctv69sv3w.17

Khalil, I., Safa, S., Yamin, A. \& Sylvestre, E. (2021) (Unpublished). Elaboration d'un référentiel de compétences de l'enseignant chercheur en méthodologie et encadrement de la recherche RCMER.

Kilburn, D., Nind, M. \&Wiles, R. (2014). Learning as researchers and teachers: The development of a pedagogical culture for social science research methods? Br. J. Educ. Stud., 62, 191-207. Retrieved from https://doi.org/10.1080/00071005.2014.918576

Koller, M., Kantzer, V., Mear, I., Zarzar, K., Martin, M., Greimel, E., ... \& ISOQOL TCASIG. (2012). The process of reconciliation: evaluation of guidelines for translating quality-of-life questionnaires. Expert review of pharmacoeconomics \& outcomes research, 12(2), 189-197. Retrieved from https://doi.org/10.1586/erp.11.102

Nunez Moscoso, J., et Murillo, A. (2017). La difficulté dans le travail enseignant : un thème de recherche aux objets pluriels. Penserl'éducation, 40, 5986. Retrieved from https://hal.archives-ouvertes.fr/hal-01684872/

Nabhani, M., \& Bahous, R. (2010). Lebanese teachers' views on 'continuing professional development'. Teacher Development, 14(2), 207-224. Retrieved from https://doi.org/10.1080/13664530.2010.494502

Nayak, B.K. (2009). Why learn research methodology? Indian J. Ophthalmol., 57, 173. Retrieved from https://doi.org/10.4103/0301-4738.49389

Nind, M., Kilburn, D., \& Luff, R. (2015). The teaching and learning of social research methods: Developments in pedagogical knowledge. Int. J. Soc. Res. Methodol., 18, 455-461. Retrieved from https://doi.org/10.1080/13645579.2015.1062631

Panda, S. (2017). Professional development of teachers in higher education. In N. V. Varghese, A. Pachauri \& S. Mandal (eds.), India Higher Education Report 2017: Teaching, Learning and Quality in Higher Education (pp132-164). New Delhi \& London: Sage Publications. Retrieved from https://doi.org/10.4135/9789353280338.n6

Pfeffer, C. A. \& Rogalin, C. L. (2012). Three strategies for teaching research methods. Teaching Sociology, 40(4), 368-376. Retrieved from https://doi.org/10.1177/0092055X12446783

Saman, E., Fereshteh, P., \& Department of Applied Linguistics, Razi University, Kermanshah, Iran. (2019). Exploring challenges in writing efl master theses: Students and supervisors' perspectives. I-manager's Journal on English Language Teaching, 9(2), 42. Retrieved from https://doi.org/10.26634/jelt.9.2.15431

Schober, B., Wagner, P., Reimann, R., Atria, M., and Spiel, C. (2006). Teaching research methods in an internet-based blended learning setting. Methodology, 2 (2) :73-82. Retrieved from https://doi.org/10.1027/16142241.2.2.73 
Suter, W. N. (2012). Introduction to educational research : A critical thinking approach. Thousand Oaks, CA: Sage. Retrieved from https://doi.org/10.4135/9781483384443

Tardif, M. (2012). Réflexivité et expérience du travail enseignant: repenser le «praticien réflexif» à la lumière des traditions de la pensée réflexive. Dans M. Tardif, C. Borges et A. Malo (Dir.), Le virage réflexif en éducation. Où en sommes-nous 30 ans après Schëm? (p.47-71). Belgique: De Boeck Supérieur s.a. Retrieved from https://doi.org/10.3917/dbu.tardi.2012.01.0047

Thiébaud, M. et Vacher, Y. (2020). L'analyse de pratiques professionnelles dans une perspective d'accompagnement, d'intelligence collective et de réflexivité. In Revue de l'analyse de pratiques professionnelles, No 18, pp. 43-69 et Le Codéveloppeur, vol 6 , no 3 . Retrieved from http://www.analysedepratique.org/?p=3716

Wilson, A., Howitt, S., Roberts, P., Akerlind, G., \& Wilson, K. (2013). Connecting expectations and experiences of students in a research-immersive degree. Studies in Higher Education, 38(10), 1562-1576. https://doi.org/10.1080/03075079.2011.633163

Zaheer, M., \& Munir, S. (2020). Research supervision in distance learning: Issues and challenges. AAOU Journal, 15(1), 131-143. Retrieved from https://doi.org/10.1108/AAOUJ-01-2020-0003 